\title{
Use and resolubility of the oral health public services offered to children in a large municipality
}

Uso e resolutividade de serviços públicos de saúde bucal ofertados a crianças em município de grande porte

Andreza Viana Lopes CARDOSO ${ }^{1}$
(i) ORCID iD 0000-0002-1023-288X
Andréa Maria Duarte VARGAS ${ }^{1}$
(D) ORCID iD 0000-0002-4371-9862
João Henrique Lara do AMARAL ${ }^{1}$
(D) ORCID iD 0000-0001-6900-7559
Mara VASCONCELOS'
(D) ORCID iD 0000-0002-0316-4591
Kecyanne Malheiros MACHADO ${ }^{1}$
(D) ORCID iD 0000-0001-6409-2766
Anna Rachel dos Santos SOARES' ${ }^{1}$
(D) ORCID iD 0000-0002-1232-1712
Raquel Conceição FERREIRA ${ }^{1}$
(iD) ORCID iD 0000-0001-8897-9345

ABSTRACT

\section{Objective}

To evaluate the effect of caries severity and socioeconomic conditions on use of oral health services and treatment situations (completed treatment, evasion, referral) among children with dental treatment needs, using the Unified Health System.

\section{Methods}

Cross sectional study performed among children up to six years old, with dental treatment needs, coming from public schools in Belo Horizonte, Brazil, examined by the Oral Health Teams in the annual survey of oral health, in 2014. Variables were collected by consulting the medical records and information systems. Services were used by children who had attended the dental appointment at least once. The severity of caries considered the number of cavitated teeth. The socioeconomic variables were: age, sex, skin color and family socioeconomic classification. Resolubility was assessed by the ratio between completed treatment and first appointment. Evasion was defined by absence in more than two consecutive unjustified appointments. Association was tested by chi-square test and Poisson regression.

Results

The frequency of services use was $44.3 \%$ and there was greater use by children with treatment needs in 4 to 8 teeth (PR=1.48, 1.23-1.78) and in more than 9 teeth $(P R=1.80,1.32-2.46)$ and lower in those with very high socioeconomic risk $(P R=0.79,0.63-0.99)$. The resolubility was of $49.6 \%$ and $5.2 \%$ abandoned the treatment. Children with lower socioeconomic status presented lower resolubility and greater avoidance.

\section{Conclusion}

The results suggested a persistent iniquity, with less use and resolubility of oral health services among children presenting worse socioeconomic status.

Indexing terms: Child, preschool. Health services research. Oral health. Patient Dropouts. Primary health care.

\section{RESUMO}

Objetivo

Avaliar o efeito da gravidade da cárie e das condições socioeconômicas no uso dos serviços de saúde bucal e nas situações de atendimento (tratamento concluído, evasão, encaminhamento) entre crianças com necessidade de tratamento odontológico usuárias do Sistema Único de Saúde.

\section{Métodos}

Estudo transversal entre crianças de até 6 anos de escolas públicas infantis, de Belo Horizonte, examinadas pelas Equipes de Saúde Bucal no levantamento anual de necessidades em saúde bucal de 2014. Foram incluídas as crianças com necessidade de tratamento odontológico. Variáveis foram coletadas por consulta ao prontuário e sistemas de informação. Usaram os serviços as crianças que compareceram pelo menos uma vez, em 2014, à consulta odontológica. A gravidade da cárie considerou o número de dentes cavitados e as variáveis socioeconômicas foram: idade, sexo, cor da pele e classificação socioeconômica da família. Resolutividade foi avaliada pela razão entre tratamento concluído

\footnotetext{
${ }^{1}$ Universidade Federal de Minas Gerais, Faculdade de Odontologia, Departamento de Odontologia Social e Preventiva. Av. Presidente Antônio Carlos, 6627, Pampulha, 31270-901, Belo Horizonte, MG, Brasil. Correspondência para / Correspondence to: AVL CARDOSO. Email: <andrezavlc@gmail. com>. 
e primeira consulta. Evasão foi definida pela ausência por $>2$ consultas consecutivas sem justificativa. Associação foi testada por teste chiquadrado e Regressão de Poisson.

\section{Resultados}

A frequência de uso de serviços foi $44,3 \%$ e houve maior uso nas crianças com necessidade de tratamento em 4 a 8 dentes (RP=1,48; 1,23$1,78)$ e em $>9$ dentes $(\mathrm{RP}=1,80 ; 1,32-2,46)$ e menor naquelas com muito elevado risco socioeconômico $(\mathrm{RP}=0,79 ; 0,63-0,99)$. A resolutividade foi de $49,6 \%$ e 5,2\% evadiram. Crianças com pior nível socioeconômico apresentaram menor resolutividade e maior evasão.

\section{Conclusão}

Sugere-se uma iniquidade persistente, com menor uso e resolutividade dos serviços de saúde bucal entre crianças com pior condição socioeconômica.

Termos de indexação: Pré-escolar. Pesquisa sobre serviços de saúde. Saúde bucal. Pacientes desistentes do tratamento. Atenção primária à saúde.

\section{INTRODUCTION}

Dental caries is the most prevalent oral disease in children, with a large number of cases at both the national and regional levels ${ }^{1-2}$, presenting inequality in their distribution between Brazilian regions and population groups ${ }^{3}$, which significantly influences the quality of life of these individuals ${ }^{4}$. Individual characteristics, such as skin color and family income as well as the addition of fluoride in water also influenced the oral health profile of preschoolers in Brazil. Children with less favorable social and economic conditions presented greater caries experience in the deciduous dentition ${ }^{3}$.

This scenario shows the iniquity in oral health and emphasizes that caries should be understood as resulting from the interaction between individual and behavioral factors, living and working conditions, food availability and access to health services and education ${ }^{5-6}$.

The organization of health services is considered a crucial determinant fact in the use of services to which we can add individual features, past experience of using services and the individual's social context ${ }^{7}$.

Child health is a strategic field of action of the National Primary Care Policy ${ }^{8}$ and the integral assistance of this group is considered strategic in the National Oral Health Policy ${ }^{9}$. According to health services protocols on child care ${ }^{10-12}$, all children, regardless to their age, should receive dental care.

The use of oral health services does not imply resolubility, which refers to the care of health needs of users with efficiency ${ }^{13}$.

Taking into consideration the prevalence of dental caries in the deciduous dentition, the presence of oral health inequities and the protocols of care for children, some questions are arisen: Are the children in need of dental treatment using the services? Have these services solved their oral health needs? Are the children most in need of dental treatment the ones who use the service most? Does the service reach socially disadvantaged children?

An evaluation of the use and resolubility of oral health services can answer these questions, contributing to the reorientation of services towards an effective, resolutive health care aimed to the population with more difficulty accessing the service. The aim of this study was to assess the association of the caries severity and socioeconomic condition with the use of oral health services and care situation (treatment completion, evasion, referral to secondary care) among children in need of dental treatment using Unified Health System.

\section{METHODS}

The research consisted of a transversal study among children up to 6 years of age enrolled in the Unified Health System (SUS) in Belo Horizonte - MG, Brazil. The city of Belo Horizonte is the capital of the State of Minas Gerais, with a projection of 2,491,109 inhabitants in 201414 and a Human Development Index of 0.811515 . The municipality is part of the Family Health Strategy (FHS) and is geographically divided into nine health districts, where, in 2014, 147 Basic Health Units (BHU) were located. At these BHU, 603 Family Health Teams and 301 Oral Health Teams (OHT) worked together.

The study scenario consisted of children, enrolled in public preschools, examined by the Oral Health Teams, in 2014. In Belo Horizonte, for the organization of oral health services, the Oral Health Team has annually surveyed the dental needs of schoolchildren, using the Dental Treatment Need Index (INTO), which quantifies the severity of caries by the number of teeth affected by the disease (Cavitated teeth) and uses the following codes and criteria: 00 and 0 - teeth without cavity and / 
or with satisfactory restorations, not requiring treatment; Codes 1, 2 and 3 - present need for dental treatment in up to 3; between 4 to 8; and 9 or more teeth, respectively. Children who have permanent or temporary teeth presenting caries and need for restoration / extraction are considered to need dental treatment and must be assisted by the dental service. Children classified with code 3 are considered a sentinel event and must receive priority service preceded by the Oral Health Team. The minimum number of children for the study was defined by a sample with data obtained in a pilot study, conducted in five Oral Health Teams, from four health districts, chosen for convenience of the study.

The estimate method for proportions was used for the sample considering the frequency of children requiring dental treatment of $34.4 \%(\alpha=0.05 ; \beta=$ 0.20 ). In this amount, $20 \%$ were added to compensate for possible losses and $22 \%$ to compensate for children who were excluded from the sample due to absence and / or incoherence of data, which was also obtained in the pilot study. After correction for finite population (total number of children examined), the minimum number of participants was 487. The selection process of the participants was represented in the flowchart (Figure 1).

For each health district of Belo Horizonte, the minimum number of participants was defined in proportion to the number of children examined in each one
(Table 1). To reach the minimum number of participants in each district, two Basic Health Units were chosen in each of them. In each Basic Health Unit, children with dental needs were identified and these were the target population for the evaluation of the use and resolubility of health services.

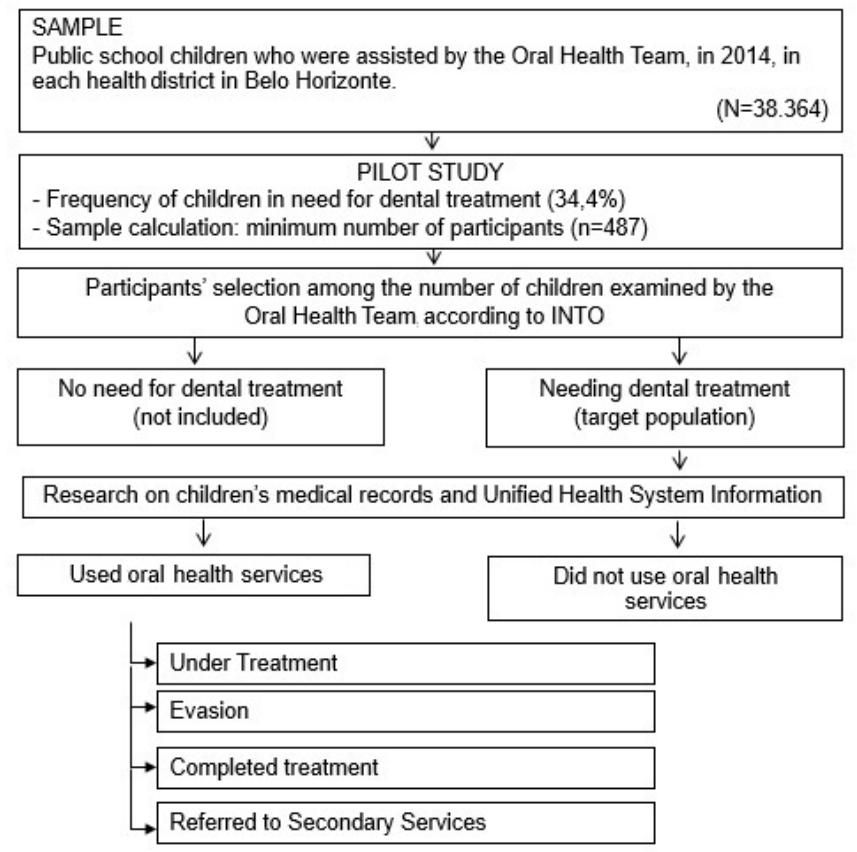

Figure 1. Flowchart showing steps of the selection of the participants.

Table 1. Number and percentage of Health Basic Units, number of Oral Health Team; minimum number of participants and number of medical records evaluated in the sanitary districts of Belo Horizonte (MG), 2014

\begin{tabular}{|c|c|c|c|c|c|c|}
\hline Sanitary Districts & $\begin{array}{c}\text { Number of } \\
\text { Health Basic } \\
\text { units in Belo } \\
\text { Horizonte } \\
n(\%)\end{array}$ & $\begin{array}{c}\text { Number of } \\
\text { Oral Health } \\
\text { Teams } \\
\text { in Belo } \\
\text { Horizonte } \\
\mathrm{n}(\%)\end{array}$ & $\begin{array}{c}\text { Children examined by } \\
\text { Oral Health Teams in } \\
\text { the public schools } \\
n(\%)\end{array}$ & $\begin{array}{l}\text { Participants's minimum } \\
\text { number in each sanitary }\end{array}$ & $\begin{array}{l}\text { Number of Health } \\
\text { Basic Units visited }\end{array}$ & $\begin{array}{l}\text { Number } \\
\text { of medical } \\
\text { records } \\
\text { evaluated ** }\end{array}$ \\
\hline Barreiro & $20(13.6)$ & $37(14.2)$ & $4994(13.0)$ & 64 & 2 & 155 \\
\hline Centro-sul & $12(8.2)$ & $17(6.5)$ & $4799(12.5)$ & 61 & 3 & 289 \\
\hline Leste & $14(9.5)$ & $24(9.2)$ & 4505 (11.7) & 58 & 2 & 119 \\
\hline Nordeste & $21(14.3)$ & $33(12.7)$ & $5626(14.7)$ & 72 & 3 & 157 \\
\hline Noroeste & $21(14.3)$ & 39 (14.9) & $4217(11.0)$ & 54 & 2 & 101 \\
\hline Norte & 19 (12.9) & 30 (11.5) & $3887(10.1)$ & 50 & 2 & 80 \\
\hline Oeste & $15(10.2)$ & $28(10.7)$ & $4095(10.7)$ & 52 & 2 & 156 \\
\hline Pampulha & $9(6.1)$ & $13(5.0)$ & $3447(9.0)$ & 44 & 2 & 49 \\
\hline Venda Nova & $16(10.9)$ & $40(15.3)$ & $2794(7.3)$ & 36 & 3 & 238 \\
\hline Total & $147(100)$ & $261(100)$ & $38.364(100)$ & 491 & 21 & 1.344 \\
\hline
\end{tabular}

Source: Municipal Secretary of Health of the City Hall of Belo Horizonte; Oral Health Technical Coordination / Care Management. * Minimum number of children in need of dental treatment in each Health Basic Unit. ** The number of medical records of children evaluated was higher than the minimum number calculated, because in each Health Basic Unit chosen, the data of all the children in need of dental treatment were evaluated.

Data were collected through consultation of children's dental records and health information systems. In the Basic Health Units which were chosen, the charts of all the children examined by the Oral 
Health Team during the determined period and who had the need for dental treatment were observed, the minimum number defined for the district could be extrapolated. When the number of charts evaluated in the two chosen Basic Health Units did not complete the calculated minimum number, another Basic Health Unit was chosen in order to complete the sample (Table 1). Data collection took place from October 2014 to March 2015.

The data obtained was related to care situations: children who did not attend the service in the year evaluated; children assisted by Oral Health Team, in 2014; treatment completed or in progress, referral to secondary care and avoidance of dental treatment (two consecutive absences, no return in 2014).

The dependent variable was the use of oral health services and the children who were treated in the period, with treatment completed or in progress and who were referred or evaded were classified in the group of children who used the services. The frequency of children who used dental services was calculated by the ratio between the number of children who had at least one appointment at Oral Health Team and the number of children in need of dental treatment.

In order to assess the factors associated with the use of oral health services, the independent variables were related to the child or his / her family: levels of dental treatment needs (INTO code 1, 2 and 3$)$, age $(<=2$ years and 3-6 Years old), skin color (white, black, yellow / dark-skinned), family socioeconomic classification (low / medium, high and very high risk) and Social Vulnerability Index (low, medium, high and very high). The information on age, sex and skin color were collected by the Community Health Agent at the moment of the user's registration at the $\mathrm{BHU}$ of his / her reference, being registered at SISREDE (SISREDE, which stores all the records of citizen's care), a source consulted in this study to obtain the data. The socioeconomic classification of the family was based on the Health Vulnerability Index. This compound index was elaborated by the Municipal Secretary of Health in the City of Belo Horizonte (SMSA / $\mathrm{PBH}$ ) and is a measure in which different socioeconomic and environmental variables are synthesized. The calculation of the Health Vulnerability Index is based on eight variables such as water supply, sanitary sewage, waste disposal, number of inhabitants per household, illiteracy, per capita income, and nominal income of heads of household and predominant ethnicity.
The categories and cutoffs defined for the total index are: low risk (sectors with Health Vulnerability Index values below the mean value), medium risk (sectors with Health Vulnerability Index values with $1 / 2$ standard deviation around average), high risk (sectors with values above the average Health Vulnerability Index up to the limit of 1.5 standard deviation above the average) and very high risk (sectors with values above the high risk Health Vulnerability)16. The family classification of each child was consulted in SISREDE. The Health Vulnerability was obtained based on the child's address; therefore the family's residence area could be identified. The Health Vulnerability Index data of Belo Horizonte are available on a map consulted on the website of the Municipality of Belo Horizonte, and the respective Health Vulnerability Index codes for each geographical sector were obtained in a municipal document with the SMSA. The Health Vulnerability Index is calculated through indicators that aim to determine the population's access to nine conditions, goods and services, of the following areas: access to housing, infrastructure, education, work, income, legal assistance, health services, guarantee of food security and access to social security.

Among the children who used the health service, the resolubility was calculated by the ratio between the number of children with completed dental treatment and the number of children who had their first appointment. We also described the frequencies of the children in treatment, the ones who had evaded and those who were referred for secondary care

Initially, the data were submitted to the descriptive analysis to characterize the participating children. The association between use of oral health services and variables related to the need for dental treatment (caries severity) and socioeconomic condition was tested by estimating the Unadjusted and Adjusted Prevalence Ratio by simple and multiple Poisson regression analysis. The variables significantly associated with the use of services remained in the multiple model $(p<0.05)$. There was no collinearity between the variables, socioeconomic classification and Health Vulnerability Index, so both were maintained in the analysis. The distribution of the sample according to the assistance was evaluated, and the chisquare test was used to evaluate a significant difference between the proportions. The statistical package SPSS v. 17.0 for data analysis.

The Research Ethics Committee of the Federal University of Minas Gerais, opinion no. 666.596/14 and 
the Research Ethics Committee of SMSA / PBH, opinion $n^{\circ} 773.635 / 14$ approved the research. All the managers of the Health Basic Units signed the Term of Consent of Use of Database.

\section{RESULTS}

Among the children enrolled in pre-school education in Belo Horizonte, in 2014, a total of 38,364 $(83.1 \%)$ were examined by the Basic Health Team in the survey of dental needs. In the Health Basic Units which were visited, there were records of the needs survey of 7,729 children, and 5,415 (70.1\%) had no need for dental treatment. Of the 2,314 children in need, 1344 (58.1\%) medical records were evaluated. There were 970 (41.9\%) children who were not found, 666 children were linked to a Health Basic Units from another assigned area and 304 (13.1\%) whose medical records were not found.

Most of the children were 4 years of age or older $(87 \%)$, male $(54.1 \%)$, dark-skinned $(64.9 \%)$, and lived in families presenting high socioeconomic risk (68.6\%), and lived in medium and high Health Vulnerability Index areas (69.4\%) (Table 2). Of the children in need of dental treatment, 891 (66.3\%), 374 (27.8\%) and 79 (5.9\%) presented needs in 1 to 3; 4 to 8 and 9 or more teeth, respectively. There was a predominance of INTO code 1, regardless of health district, age, sex, skin color, socioeconomic classification and Health Vulnerability Index (Table 2).

Table 2. Characterization of children up to 6 years old and with different levels of dental treatment need according to health district and socioeconomic variables. Belo Horizonte, Minas Gerais, Brazil ( $n=1,344)$. 2014.

\begin{tabular}{|c|c|c|c|c|}
\hline \multirow[b]{2}{*}{ Variable } & \multirow[b]{2}{*}{$\begin{array}{l}\text { Total sample } \\
\text { n (\%) }\end{array}$} & \multicolumn{3}{|l|}{ Levels of need ( INTO Code) } \\
\hline & & $\begin{array}{c}\text { INTO } 1 \text { ( Up to } 3 \text { carious teeth) } \\
\text { n (\%) }\end{array}$ & $\begin{array}{c}\text { INTO } 2 \text { (from } 4 \text { to } 8 \text { carious } \\
\text { teeth) } \\
\text { n }(\%)\end{array}$ & $\begin{array}{c}\text { INTO } 3 \text { (9 or more carious } \\
\text { teeth ) } \\
n(\%)\end{array}$ \\
\hline \multicolumn{5}{|c|}{ Sanitary District (1344) } \\
\hline Barreiro & $155(11.5)$ & $95(61.3)$ & $51(32.9)$ & $9(5.8)$ \\
\hline Centro-sul & $289(21.5)$ & $178(61.6)$ & $93(32.2)$ & $18(6.2)$ \\
\hline Leste & $119(8.9)$ & $79(66.4)$ & $30(25.2)$ & $10(8.4)$ \\
\hline Nordeste & $157(11.7)$ & $99(63.1)$ & $51(32.5)$ & $7(4.5)$ \\
\hline Noroeste & $101(7.5)$ & $70(69.3)$ & $26(25.7)$ & $5(5.0)$ \\
\hline Norte & $80(6.0)$ & $63(78.8)$ & $12(15.0)$ & $5(6.3)$ \\
\hline Oeste & $156(11.6)$ & $127(81.4)$ & $27(17.3)$ & $2(1.3)$ \\
\hline Pampulha & $49(3.6)$ & $39(79.6)$ & $8(16.3)$ & $2(4.1)$ \\
\hline Venda Nova & $238(11.7)$ & $141(59.2)$ & $76(31.9)$ & $21(8.8)$ \\
\hline \multicolumn{5}{|l|}{ Age (1344) } \\
\hline 1 & $4(0.3)$ & $3(75.0)$ & $1(25.0)$ & 0 \\
\hline 2 & $23(1.7)$ & $12(52.2)$ & $8(34.8)$ & $3(13.0)$ \\
\hline 3 & $147(10.9)$ & $103(70.1)$ & $40(27.2)$ & $4(2.7)$ \\
\hline 4 & $332(24.7)$ & $219(66.0)$ & $89(26.8)$ & $24(7.2)$ \\
\hline 5 & $424(31.5)$ & 275 (64.9) & $123(29.0)$ & $26(6.1)$ \\
\hline 6 & $414(30.8)$ & $279(67.4)$ & $113(27.3)$ & $22(5.3)$ \\
\hline \multicolumn{5}{|l|}{ Sex (1344) } \\
\hline Male & $727(54.1)$ & $480(66.0)$ & 203 (27.9) & $44(6.1)$ \\
\hline Female & $617(45.9)$ & $411(66.6)$ & $171(27.7)$ & $35(5.7)$ \\
\hline \multicolumn{5}{|c|}{ Skin Color (870) } \\
\hline White & $210(24.1)$ & $148(70.5)$ & $51(24.3)$ & $11(5.2)$ \\
\hline Black & $81(9.3)$ & $53(65.4)$ & $22(27.2)$ & $6(7.4)$ \\
\hline Yellow & $14(1.6)$ & $12(85.7)$ & $2(14.3)$ & 0 \\
\hline Dark-skinned & 565 (64.9) & 350 (61.9) & $177(31.3)$ & $38(6.7)$ \\
\hline \multicolumn{5}{|c|}{$\begin{array}{l}\text { Socioeconomic } \\
\text { Classification (1047) }\end{array}$} \\
\hline No risk & $52(5.0)$ & $30(57.7)$ & $19(36.5)$ & $3(5.8)$ \\
\hline Low risk & $90(8.6)$ & $60(66.7)$ & $25(27.8)$ & $5(5.6)$ \\
\hline Medium risk & $187(17.9)$ & $129(69.0)$ & $51(27.3)$ & $7(3.7)$ \\
\hline High risk & $429(41.0)$ & $269(62.7)$ & $134(31.2)$ & $26(6.1)$ \\
\hline Very high risk & $289(27.6)$ & $190(65.7)$ & $76(26.3)$ & $23(8.0)$ \\
\hline \multicolumn{5}{|c|}{$\begin{array}{l}\text { Social Vulnerability Index } \\
\text { (1137) }\end{array}$} \\
\hline Low & $48(4.2)$ & $38(79.2)$ & $9(18.8)$ & $1(2.1)$ \\
\hline Médium & $418(36.8)$ & $275(65.8)$ & $113(27.0)$ & $30(7.2)$ \\
\hline High & $371(32.6)$ & $245(66.0)$ & $108(29.1)$ & $18(4.9)$ \\
\hline Very high & $300(26.4)$ & $183(61.0)$ & $95(31.7)$ & $22(7.3)$ \\
\hline
\end{tabular}


Of all the children in need, 749 (55.7\%) did not use the dental service, in 2014. The variables associated with the use of dental services were level of need and family socioeconomic classification. The prevalence of use of services was higher in children who needed treatment in 4 to 8 teeth $(\mathrm{RP}=1.48,95 \% \mathrm{Cl}: 1.23-1.78)$ and in 9 or more teeth $(\mathrm{RP}=1.80 ; 95 \% \mathrm{Cl}: 1.32-2.46)$ and lower in those with a very high socioeconomic risk $(P R=0.79,95 \% \mathrm{Cl}: 0.63-0.99)$ (Table 3). The variables age, sex, skin color and Health Vulnerability Index were not significantly associated with the use of dental services (Table 3).

Table 3. Bivariate and multiple analysis of the association between the use of oral health services and levels of need for dental treatment, age, sex, skin color, socioeconomic classification and Social Vulnerability Index. Belo Horizonte (MG), 2014.

\begin{tabular}{|c|c|c|c|c|}
\hline & \multicolumn{4}{|c|}{ Oral Health Service Use } \\
\hline & $\begin{array}{c}\text { Yes }(n=595) \\
n(\%)\end{array}$ & $\begin{array}{c}\text { No } \\
(n=749) \\
n(\%)\end{array}$ & PRunadjusted & PRadjusted* \\
\hline \multicolumn{5}{|c|}{ Levels of Need (INTO Code) } \\
\hline Up to 3 teeth in need & $333(37.4)$ & $558(62.6)$ & 1 & 1 \\
\hline From 4 to 8 teeth in need & $207(55.3)$ & $167(44.7)$ & $1.48(1.25-1.70)$ & $1.48(1.23-1.78)$ \\
\hline 9 or more teeth in need & $55(69.6)$ & $24(30.4)$ & $1.86(1.40-2.48)$ & $1.80(1.32-2.46)$ \\
\hline \multicolumn{5}{|l|}{ Age } \\
\hline$<2$ years old & $11(54.8)$ & $95(45.2)$ & 1 & \\
\hline 3 or more years old & $584(44.3)$ & $733(55.7)$ & $1.08(0.60-1.98)$ & - \\
\hline \multicolumn{5}{|l|}{ Sex } \\
\hline Male & $311(42.8)$ & $416(57.2)$ & 1 & - \\
\hline Female & $284(46.0)$ & $333(54.0)$ & $1.08(0.92-1.26)$ & \\
\hline \multicolumn{5}{|l|}{ Skin Color } \\
\hline White & $115(54.8)$ & $95(45.2)$ & 1 & \\
\hline Black & $35(43.2)$ & $46(56.8)$ & $0.78(0.54-1.15)$ & - \\
\hline Yellow and dark & $276(47.7)$ & $303(52.3)$ & $0.87(0.70-1.08)$ & \\
\hline \multicolumn{5}{|c|}{ Socioeconomic Classification } \\
\hline No/low/average risk & $173(52.6)$ & $156(47.4)$ & 1 & \\
\hline High risk & $211(49.2)$ & $218(50.8)$ & $0.93(0.77-1.14)$ & $0.92(0.75-1.1)$ \\
\hline very high_risk & $122(42.2)$ & $167(57.8)$ & $0.80(0.64-0.99)$ & $0.79(0.63-0.99)$ \\
\hline \multicolumn{5}{|l|}{ Social Vulnerability Index } \\
\hline Low/medium & $169(45.6)$ & $202(54.4)$ & 1 & - \\
\hline High & $121(40.3)$ & $179(59.7)$ & $0.85(0.70-1.04)$ & \\
\hline Very high & $539(47.4)$ & $598(52.6)$ & $0.83(0.65-1.05)$ & \\
\hline
\end{tabular}

Note: * Model adjusted according to age and sex

Table 4. Characterization of children up to 6 years of age who needed dental treatment and who used oral health services in 2014 according to the situation of dental care. Belo Horizonte, Minas Gerais, Brazil (n=595). 2014.

\begin{tabular}{|c|c|c|c|c|}
\hline & \multicolumn{4}{|c|}{ Oral treatment attendance } \\
\hline & $\begin{array}{c}\text { Treatment } \\
\text { completed } \\
\mathrm{n}(\%)\end{array}$ & $\begin{array}{c}\text { Under treatment } \\
\mathrm{n}(\%)\end{array}$ & $\begin{array}{l}\text { Evasion } \\
\mathrm{n}(\%)\end{array}$ & $\begin{array}{c}\text { Referred to secondary } \\
\text { n (\%) }\end{array}$ \\
\hline Total sample & $295(49.6)$ & $208(35.0)$ & $31(5.2)$ & $61(10.2)$ \\
\hline \multicolumn{5}{|c|}{ Levels of Need (INTO code) $(p<0.001)$} \\
\hline Up to 3 teeth in need & $201(60.4)$ & $89(22.7)$ & $14(4.2)$ & $29(8.7)$ \\
\hline From 4 to 8 teeth in need & $84(40.6)$ & $93(44.9)$ & $12(5.8)$ & $18(8.7)$ \\
\hline $\begin{array}{l}9 \text { or more teeth in need } \\
\text { Sanitary District }(p<0.001)\end{array}$ & $10(18.2)$ & $26(47.3)$ & $5(9.1)$ & $14(25.5)$ \\
\hline Centro-sul & $54(52.4)$ & $43(41.7)$ & $2(1.9)$ & $4(3.9)$ \\
\hline Leste & $19(27.1)$ & $35(50.0)$ & $1(1.4)$ & $15(21.4)$ \\
\hline Nordeste & $58(62.4)$ & $19(20.4)$ & $5(5.4)$ & $11(11.8)$ \\
\hline Noroeste & $19(50.0)$ & $10(26.3)$ & $2(5.3)$ & $7(18.4)$ \\
\hline Norte & $24(72.7)$ & $7(21.2)$ & $2(6.1)$ & 0 \\
\hline Oeste & $20(58.8)$ & $9(26.5)$ & $3(8.8)$ & $2(5.9)$ \\
\hline 3 years or more & $292(50.0)$ & $202(34.6)$ & $31(5.3)$ & $59(10.1)$ \\
\hline
\end{tabular}




\begin{tabular}{|c|c|c|c|c|}
\hline \multicolumn{5}{|l|}{$\operatorname{Sex}(p=0.206)$} \\
\hline Male & $165(53.1)$ & $103(33.1)$ & $17(5.5)$ & $26(8.4)$ \\
\hline Female & $130(45.8)$ & $105(37.0)$ & $14(4.9)$ & $35(12.3)$ \\
\hline \multicolumn{5}{|l|}{ Skin color $(p=0.373)$} \\
\hline White & $58(50.4)$ & $40(34.8)$ & $8(7.0)$ & $9(7.8)$ \\
\hline Black & $20(57.1)$ & $13(37.1)$ & $1(2.9)$ & $1(2.9)$ \\
\hline Yellow or dark & $120(43.5)$ & $107(38.8)$ & $13(4.7)$ & $36(13.0)$ \\
\hline \multicolumn{5}{|c|}{$\begin{array}{l}\text { Socioeconomic } \\
\text { classification }(p=0.03)\end{array}$} \\
\hline No/low/medium risk & $95(54.9)$ & $54(31.2)$ & $5(2.9)$ & $19(11.0)$ \\
\hline High risk & $100(47.4)$ & $79(37.4)$ & $11(5.2)$ & $21(10.0)$ \\
\hline Very high risk & $55(45.1)$ & $46(37.7)$ & $12(9.8)$ & $9(7.4)$ \\
\hline \multicolumn{5}{|c|}{$\begin{array}{l}\text { Social Vulnerability Index } \\
(p=0.243)\end{array}$} \\
\hline Low/medium & $122(49.0)$ & 87 (34.9) & $10(4.0)$ & $30(12.0)$ \\
\hline High & $88(52.1)$ & $51(30.2)$ & $14(8.3)$ & $16(9.5)$ \\
\hline Very high & $57(47.1)$ & $54(44.6)$ & $3(2.5)$ & $7(5.8)$ \\
\hline
\end{tabular}

Of the 595 (44.3\%) children who used the service, $49.6 \%$ had their dental treatment completed (resolubility); $35 \%$ were on treatment; $5.2 \%$ evaded and $10.2 \%$ were referred to secondary care. There was a statistically significant difference between the frequencies of dental care situations of children according to levels of dental treatment needs and socioeconomic classification of the family. The highest frequency of completed treatment was observed among children with up to 3 teeth in need for treatment teeth and with low and medium socioeconomic risk. Children who needed treatment in 9 or more teeth had a higher frequency in other care situations: in treatment, avoidance and referral. Those with a high socioeconomic risk had a higher frequency of avoidance of oral health services. There was a statistically significant difference between the frequencies of dental care situations according to Belo Horizonte health districts (Table 4).

\section{DISCUSSION}

The use and resolubility of oral health services offered to children up to 6 years of age in Belo Horizonte - MG is still impaired and there is an iniquity in the use of these services, which presents difficulties in reaching children presenting worse socioeconomic classifications. Children presenting higher numbers of teeth needing treatment showed higher frequency of service use, which was lower compared to those classified as having a very high socioeconomic risk.

More than half of the children who needed dental treatment did not use the services. Studies have evaluated the use of lifelong services or periods of up to one year prior to the interview ${ }^{16-21}$, regardless the child's need for dental treatment. No studies were found which took into consideration the use of dental professional services among children in need of treatment. Two national studies, among children up to 5 years old, found that $86.7 \% 20$ and $79.3 \%,{ }^{22}$ respectively, never used the dental service. Likewise, PNAD 2008 data revealed that, in children up to 4 years of age, $77.9 \%$ had never been to the dentist. The lowest non-use prevalence (55.7\%) observed in this study when compared to population-based studies is explained by the fact that it represents a sample of children who need treatment. In addition, the prevalence of non-use of services observed in this study may have been underestimated, since children without medical records were excluded. The inclusion of these children among those who did not use the services, would show $78.3 \%$, a percentage close to those observed in the population-based studies.

The observed results can show impairment in children's access to oral health services, by either features related to the service or to the child, his or her family and their life context. Low perceived need in oral health by the child's parents/guardians ${ }^{23}$, time schedule not compatible with the demand ${ }^{20}$ and high repressed demand can increase the number of appointment absences ${ }^{22}$. In addition to supervised oral hygiene actions ${ }^{9}$ and topical application of fluoride ${ }^{9}$, an initiative that can increase children's access to dental services is the Health in School Program - HSP, as an intersectoral strategy between the Ministries of Health and Education in order to promote integral health care of the students in the public education ${ }^{23}$.

Children with higher numbers of teeth needing treatment showed a higher prevalence of service use, which has also been observed in other studies ${ }^{24-25}$.

The Oral Health Teams $n$ Belo Horizonte provide surveys concerning oral health needs in schoolchildren, 
quantifying carious teeth, data used in order to prioritize the treatment of more serious cases. This prioritization may explain the greater use of services among children with more affected teeth, besides showing equity. Nonetheless, while organizing access by the severity of the disease, children with oral health conditions considered less serious (code INTO 1 and 2) have their access impaired at the service. Therefore, strategies should be sought in order to ensure that INTO codes 1 and 2, such as providing atraumatic restorative treatment - ART - in schools, a procedure which would eliminate impairments related to the family, such as scheduling the appointment during the working hours of those responsible, and geographic distances to the Health Basic units.

Moreover, INTO has too extensive classification codes, which insert, for example, at the same level (code 2), children who present 4 to 8 teeth needing treatment. It is suggested that the index used for the classification brings codes with smaller intervals, thus increasing its perception in order to better evaluate the oral health observed.

Less use of oral health services among children presenting worse socioeconomic conditions was observed, regardless of their need for dental treatment, although greater use of services was expected in this group, since it has been observed in previous studies an association between unfavorable living conditions and higher levels of dental caries $^{3}$, increasing the need for treatment, which, in turn, triggers the use of dental services ${ }^{24}$. In the present study, socioeconomic factors, besides the need for dental treatment, determined the use of oral health services. The socioeconomic risk indicator, adopted by the municipality and used in this study, synthesizes socioeconomic and environmental variables, such as water supply, sanitary sewage, illiteracy and per capita income. Greater socioeconomic risk may represent a life setting unfavorable to the use of services, low perception of the need for treatment, low empowerment, small healthy choices and service absenteeism ${ }^{3,22}$.

Characteristics of people's life context, which favor or impair the use of services, besides the clinical condition of the individual, should be included in the definition of the prioritization criteria.

Considering that in the municipality evaluated, the Primary Care services are organized in a decentralized network, with coverage of the oral health services of $43.3 \%$ of the municipality estimated population, in $2014^{26}$, the results point to a persistent iniquity, suggesting that the provision of services does not guarantee the children's use the oral health service. Furthermore, in large urban agglomerations, organizational gaps may be found, since in these places the major problems of service integration are more evident due to the historical accumulation of different institutional cultures and complex population demands, as well as.

The frequency of children regarding dental care varied among districts, supporting the hypothesis that organizational factors and social disparities may facilitate or hinder the use of oral health services.Lower prevalence of completed treatment was observed as well as higher prevalence of evasion (nine or more teeth requiring dental treatment) among children of very high socioeconomic risk. The absence of children, even in the presence of much need, was observed showing that there was service offer, although the actions of the Oral Health Team have not been evaluated, in this situation. Although these children are followed as an active search protocol, absenteeism can still be found. It is strongly suggested that discussions of strategies capable of assisting these more complex cases which involve primary and secondary health care are allowed.

Regarding the resolubility, approximately half of the children did not complete the treatment, a result lower than that observed in Marília - SP, of $83.6 \%{ }^{13}$. In the study performed in the city of Marília -State of São Paulo, the relationship between completed treatment and first appointment was used in the comparison of the resolution between the oral health service offered to children older than 2 years old, by teams linked or not to Health Family Strategies ${ }^{13}$. The authors observed that the resolubility of $83.6 \%$ of the Oral Health Team in the Family Health Strategies was twice as great as that obtained by the teams that worked in the traditional model ${ }^{13}$. The lower resolubility observed in the present study can be explained by the inclusion of only children up to 6 years of age, who may require more appointments in order to complete treatment, due to clinical and behavioral management, and to absenteeism ${ }^{22}$. No other studies on health service resolubility were found, which made it difficult to compare the results. When children with ongoing treatment (35\%) were added to the percentage of children with completed treatment $(49.6 \%)$, it was found that the service has been responding to dental needs through clinical care, a fact reinforced by the observation of greater prevalence of sentinel children under treatment.

Estimates of the children's need for dental treatment do not represent the situation of the municipality, 
since the sample was obtained among those enrolled in the early childhood education in public schools, who were examined by the Oral Health Team and presented the need for dental treatment. This methodological choice is justified by the importance of evaluating the service and its organizational practice. Private school children were not included in the study.

\section{CONCLUSION}

Children oral health care for is still a challenging reality for health services. The results reveal persistent inequities in the use and resolubility of oral health

\section{REFERENCES}

1. Brasil. Ministério da Saúde. Secretaria de Atenção à Saúde. Secretaria de Vigilância em Saúde. SB Brasil 2010: Pesquisa Nacional de Saúde Bucal: Resultados Principais. Brasília: Ministério da Saúde; 2012 [citado 2017 Fev 10]. Disponível em: < http://bvsms.saude.gov.br/bvs/publicacoes/pesquisa_ nacional_saude_bucal.pdf>.

2. Minas Gerais. Secretaria de Estado de Saúde de Minas Gerais. SB Minas Gerais: Pesquisa das Condições de Saúde Bucal da População Mineira: Resultados Principais. Belo Horizonte: Secretaria de Estado de Saúde de Minas Gerais; 2013 [citado 2017 Fev 10]. Disponível em: <http://www.saude.mg.gov.br/ images/documentos/SBMinas_Relatorio_Final.pdf

3. Ardenghi TM, Piovesan C, Antunes JLF. Inequalities in untreated dental caries prevalence in preschool children in Brazil. Rev Saude Publica. 2013;47(S3):129-37. doi: 10.1590/S00348910.2013047004352

4. Ortiz FR, Ramadan YH, Bayardo González RA, Ardenghi TM. Factors associated with oral health-related quality of life of preschool children in Southern Brazil. RGO, Rev Gauch Odontol. 2016;64(3):256-62. doi: 10.1590/1981863720160003000033254

5. Duijster D, Van Loveren C, Dusseldorp E, Verrips GHW. Modelling community, family and individual determinants of childhood dental caries. Eur J Oral Sci. 2014;122(2):125-33. doi: 10.1111/ eos. 12118

6. Melo MMDC, Souza WV, Tavares MC, Lima MLC, Jamelli S, Couto GBL. Social conditions and high levels of dental caries in five-year-old children in Brazil. J Dent Child. 2015;82(1):29-35.

7. Andersen RM, Newman JF. Societal and individual determinants of medical care utilization in the United States. Milbank Mem Fund Q. 1973; 51: 95-124. doi: 10.1111/j.14680009.2005.00428.x.

8. Brasil. Ministério da Saúde. Secretaria de Atenção à Saúde. Departamento de Atenção Básica. Política Nacional de Atenção Básica. Brasília: Ministério da Saúde; 20122012 [citado 2017 Fev 10]. Disponível em: <http://189.28.128.100/dab/docs/ publicacoes/geral/pnab.pdf>. services, which were lower for children presenting worse socioeconomic status.

\section{Collaborators}

AVL CARDOSO, ARSS OARES, KM MACHADO performed the data collection and participated in the analysis and interpretation of data and the writing of the manuscript. AMD VARGAS and M VASCONCELOS participated in the interpretation of the results and contributed to the drafting of the manuscript. JHLA AMARAL and RC FERREIRA designed the study and participated in the analysis and interpretation of the results. All authors reviewed a final version of the article.

9. Brasil. Ministério da Saúde. Secretaria de Atenção à Saúde Departamento de Atenção Básica. Coordenação Nacional de Saúde Bucal. Diretrizes da Política Nacional de Saúde Bucal. Brasília: Ministério da Saúde; 2004 [citado 2017 Fev 10]. Disponível em: <http://189.28.128.100/dab/docs/publicacoes/ geral/diretrizes_da_politica_nacional_de_saude_bucal.pdf>.

10. Belo Horizonte. Secretaria Municipal de Saúde de Belo Horizonte. BH Viva Criança: compromisso com a assistência integral à saúde da criança e adolescente. Belo Horizonte: Secretaria Municipal de Saúde de Belo Horizonte; 2004 [citado 2017 Fev 25]. Disponível em: <http://www.pbh.gov.br/smsa/biblioteca/ geas/agendadacrianca.pdf>

11. Minas Gerais. Secretaria de Estado de Saúde de Minas Gerais Atenção à saúde da criança. Belo Horizonte: Secretaria de Estado de Saúde de Minas Gerais; 2005 [citado 2017 Fev 25]. Disponível em: < http://www.atenas.edu.br/Faculdade/material/ interação/Manual\%20Atenção\%20à\%20Saúde\%20da\%20 CRIANÇA.pdf>.

12. Brasil. Ministério da Saúde. Secretaria de Atenção à Saúde Departamento de Atenção Básica. Cadernos de Atenção Básica. Saúde da criança: crescimento e desenvolvimento. Brasília: Ministério da Saúde; 2012 [citado 2017 Fev 25]. Disponível em: <http://189.28.128.100/dab/docs/publicacoes/cadernos_ab/ caderno_33.pdf>

13. Bulgareli J, Cortellazzi KL, Ambrosano GMB, Meneghim MC, Faria $E T$, Mialhe $F L$, et al. A resolutividade em saúde bucal na atenção básica como instrumento para avaliação dos modelos de atenção. Cien Saude Colet. 2014;19(2):383-91. doi: 10.1590/1413-81232014192.20102012

14. Instituto Brasileiro de Geografia e Estatística. Estimativa da população residente em Belo Horizonte em 2014. 2014 [citado 2015 Jun 26]. Disponível em: <http://cidades.ibge.gov.br/xtras/ perfil.php?codmun=310620>

15. Programa das Nações Unidas para o Desenvolvimento. Ranking IDHM Municípios 2010. 2010 [citado 2015 Jun 26]. Disponível em: $\quad<h t t p: / / w w w . p n u d . o r g . b r / a t l a s / r a n k i n g / r a n k i n g-i d h m-$ municipios-2010.aspx>

16. Brasil. Ministério da Saúde. Cadastro Nacional de Estabelecimentos de Saúde. 2014 [citado 2015 Jun 26]. Disponível em: <http://cnes.datasus.gov.br/Lista_Es_Municipio. 
asp?VEstado=31\&VCodMunicipio $=310620 \&$ NomeEstado $=>$

17. Minas Gerais. Prefeitura Municipal de Belo Horizonte. Secretaria Municipal de Saúde. Índice de Vulnerabilidade da Saúde 2012. Belo Horizonte: SMSA/PBH, 2013b

18. Instituto Brasileiro de Geografia e Estatística. Pesquisa Nacional por Amostra de Domicílios: um panorama da saúde no Brasil: acesso e utilização de serviços, condições de saúde e fatores de risco e proteção à saúde - 2008. 2008 [citado 2015 jun 30]. Disponível em: <http://www.ibge.gov.br/home/estatistica/ populacao/trabalhoerendimento/pnad2008/>

19. Baldani $\mathrm{MH}$, Antunes JLF. Inequalities in access and utilization of dental services: a cross-sectional study in an area covered by the Family Health Strategy. Cad Saude Publica. 2011;27(2):S272-83. doi: 10.1590/S0102-311X2011001400014

20. Kramer PF, Ardenghi TM, Ferreira S, Fischer LA, Cardoso L, Feldens CA. Utilização de serviços odontológicos por crianças de 0 a 5 anos de idade no município de Canela, Rio Grande do Sul, Brasil. Cad Saude Publica. 2008;24(1):150-6. doi: 10.1590/ S0102-311X2008000100015

21. Müller IB, Castilhos ED, Camargo MBJ, Gonçalves H. Experiência de cárie e utilização do serviço público odontológico por escolares: estudo descritivo em Arroio do Padre, Rio Grande do Sul, 2013. Epidemiol Serv Saude. 2015; 24(3): 759-770. doi: $10.5123 /$ S1679-49742015000400018

22. Goettems ML, Ardenghi TM, Demarco FF, Romano AR, Torriani DD. Children's use of dental services: influence of maternal dental anxiety, attendance pattern, and perception of children's quality of life. Community Dent Oral Epidemiol. 2012;40(5):4518. doi: 10.1111/j.1600-0528.2012.00694.x

23. Rodrigues LAM, Martins AMEBL, Silveira MF, Ferreira RC, Souza JGS, Silva JM, et al. Uso de serviços odontológicos entre pré-escolares: estudo de base populacional. Cien
Saude Colet. 2014;19(10):4247-56. doi: 10.1590/1413812320141910.13382013

24. Gonçalves $\mathrm{CA}$, Vazquez FL, Ambrosano GMB, Mialhe FL, Pereira $A C$, Sarracini KLM, et al. Estratégias para o enfrentamento do absenteísmo em consultas odontológicas nas Unidades de Saúde da Família de um município de grande porte: uma pesquisa-ação. Cien Saude Colet. 2015;20(2):449-60. doi: 10.1590/1413-81232015202.00702014

25. Brasil. Casa Civil. Decreto n. 6.286, de 5 de dezembro de 2007. Institui o Programa Saúde na Escola - PSE, e dá outras providências. Diário Oficial da República Federativa do Brasil, Brasília (DF); 2007 dez 06; Seção 1: 22008 [citado 2015 jun 30]. Disponível em: <http://www.planalto.gov.br/ccivil_03/_ ato2007-2010/2007/decreto/d6286.htm>.

26. Machry RV, Tuchtenhagen S, Agostini BA, Teixeira CRS, Piovesan $C$, Mendes FM, et al. Socioeconomic and psychosocial predictors of dental healthcare use among Brazilian preschool children. BMC Oral Health. 2013;13:60. doi: 10.1186/1472-6831-13-60

27. Belo Horizonte. Prefeitura Municipal de Belo Horizonte. Relatório de Gestão 2014 - Secretaria Municipal de Saúde. [Internet]. Belo Horizonte: Prefeitura Municipal de Belo Horizonte (MG); 2014 [citado 2016 fev 29]. Disponível em:<file:///C:/Users/Andrezavlc/ Downloads/relatorio-gestao-2014-final\%20(1).pdf>
Received on: 30/3/2017

Final version resubmitted on: 7/7/2017

Approved on: 27/10/2017 